\title{
Reassessing the pauper burial: the disposal of corpses in nineteenth- century Brussels
}

\section{Jolien Gijbels}

In this article I examine the changing disposal of pauper corpses in the nineteenthcentury hospitals of Brussels. I argue that the end of the century witnessed a growing focus on the individuality of the pauper corpse. Research into hospital records has revealed the significance of the ideological struggles between Catholics, liberals and socialists from the 1860s onwards, as a result of which the indifferent attitude of hospital administrators regarding dead patients and relatives was increasingly contested. Acts and complaints by the local authorities, mutualist burial societies and relatives brought about improvements of the material conditions of the pauper burial. My analysis of this debate shows that the ideological conflicts regarding Catholic and civil burials, as well as the introduction of new burial standards within hospitals, led to a greater emphasis on the burial desires of the dead. Yet, I argue that this attention towards the individual pauper corpse was only deemed necessary if close family members or burial societies stood up for the fulfilment of the dying wishes of the dead. Poor hospital patients without such social relationships could not prevent an anonymous anatomy burial.

Keywords: Pauper burial, ideological conflict, Belgium, nineteenth century, materiality, corpse

\section{Introduction}

Paupers were afraid of dying in nineteenth-century hospitals. The anonymous burial of their dissected remains in plain coffins contrasted sharply with the increasingly individualized and sentimental funerals of upper and middle class families. Studies on death with a focus on funeral and mourning rituals in wealthy Victorian families have emphasized this contrast (Houlbrooke, 1989; Jalland, 1996; Pearsall, 1999; Wolffe, 2000), while medical historians have argued that the anatomization of the poor started a process of objectification. Against their will, deceased patients often ended upon the dissection table to be studied as scientific 'objects' of interest (Hurren, 2012; MacDonald, 2006; Richardson, 1987). As anatomists turned body parts into objects of scientific value, the mortal remains gradually lost their references to the identity of the deceased. Historians have also explained dehumanization as a medical attitude to distance oneself 
from the corpse. Since a dissection implied the severe mutilation of a human body, it was necessary to rule out emotions during medical interventions (Alberti, 2011, pp. 99-101; Carol, 2011, p.73; Le Breton, 1993, p.21).

Fragmented and excluded from commemorative rites, it is indeed hard to imagine the anatomized pauper corpse as a 'social' object. Nevertheless, hospitals constantly had to deal with relatives and burial societies who claimed ownership over the bodies of deceased patients. By putting forward their right to see and bury the pauper corpse, survivors were able to pay their last respects to their loved ones. The social function of dead bodies, through which the identities of both the deceased and the mourners are expressed and (re)constructed, has recently been emphasized by scholars within various disciplines. In this interdisciplinary debate, corpses have been conceptualized as 'relational entities', connecting the living to the deceased (Hallam, Hockey, \& Howarth, 1999; Harper, 2010; Lambert \& McDonald, 2013; Schwartz, 2015; Watson \& Cunningham-Burley, 2001). Contrary to other objects, dead bodies are still part of ongoing social relationships. Especially to relatives, the corpse is a material presence that embodies an absence, an absence to which it continually refers.

In the second half of the nineteenth century, physicians became more sensitive to the personhood of pauper corpses. While forensic pathologists received the absolute freedom to investigate the whole of the body, normal autopsies confined themselves more to the necessary organs because families could come and see the body afterwards. Anatomists left the face and hands of the deceased intact, so that relatives could still recognize their loved ones (Claes \& Huistra, 2016, pp. 40-44; Menenteau, 2009, pp. 3640, 2013, pp. 266-288). Whereas post-mortem examinations occurred in exclusively medical settings, questions related to the identity and integrity of the pauper corpse especially came to the fore during the disposal of the pauper body. This symbolic, often sacred, moment will be the central focus of this article. Drawing upon city archives and hospital records preserved in the underused archives of the Social Services, this article will address the disposal of pauper corpses in the two main public hospitals of Brussels, Saint-Jean and Saint-Pierre. My analysis of these records, covering, among other things, correspondence, meeting reports and hospital regulations, shows the changes in hospital practices as a result of social concerns and political divides in the period 1850-1914. As the pauper corpse became a stake in the ideological struggle between Catholics, liberals and socialists, indifferent attitudes toward corpses within hospitals were increasingly contested. The Belgian capital Brussels is a particularly interesting case to investigate because intense political tensions in the second half of the nineteenth century had a profound impact on the policies of the liberal city council toward pauper burials.

Central to this analysis will be a consideration of the material corpse and the materialities surrounding the disposal of pauper bodies. Recent archaeological and anthropological research has shown the importance of the material setting, the material body and symbolic objects during mortuary practices in maintaining connections to the deceased (Fahlander \& Oestigaard, 2008; Hallam \& Hockey, 2001; Tarlow, 2002). By analyzing the negotiations over the pauper corpse from the perspectives of the hospital administrators and of the city council, relatives and mutualist burial societies, this article will explain how the material conditions of the pauper burial improved in late-nineteenthcentury Brussels. In order to contextualize the debate, the first part of the essay will consider customs and procedures in the disposal of pauper corpses within nineteenthcentury public hospitals. The following two sections will look into the influence of socio- 
political developments on changes to the treatment of the pauper corpse in hospitals. I will show how ideological struggles between liberals and Catholics in the 1860s resulted in the rise of anticlerical and Catholic burial societies. These new actors, operating within and beyond hospitals, were the first to promote decent funeral rites of paupers. Influenced by liberal ideas and pressed by socialist manifestations, the city council of Brussels emerged as a powerful actor pressing for improvements in the burial conditions of dead patients from the 1880s onwards. Finally, I will argue that the increasing level of care towards the individual pauper corpse led to a growing recognition of the last wishes of the deceased at the turn of the century. In the name of dead paupers, family members and burial societies stood up for the fulfilment of their burial desires.

\section{'Buried as a dog'}

In the nineteenth century, public hospitals functioned as charitable institutions, housing especially poor patients who could not afford their hospital treatment. According to Belgian legislation on dissection, which was based on French law, medical men could use the unclaimed corpses of dead hospital patients (Brouckère \& Tielemans, 1834, p. 199; 1838, p.61). The principle behind Belgian and European regulations was that claims to a corpse involved financial responsibilities (Buklijas, 2008, pp. 4-6; Hurren, 2012, pp. 579580, 585). Families could only prevent post-mortem examinations if they covered the hospital treatment or burial costs. In Brussels, hospitals organised the allocation of the dead to the amphitheatre if the relatives had not paid for the burial within 24 hours of death. Consequently, poor families were often unable to claim the bodies of their beloved ones, because they had insufficient time to garner the makeshift economy of their kinship networks. With the establishment of the autopsy service in the hospitals of Brussels in 1878 , the corpses of unclaimed dead patients were first used for scientific research, after which the autopsied body parts were dissected during medical classes (Claes \& Huistra, 2016, pp.49-51).

The disposal of human remains was a daily reality in the anatomical theatre, where staff collected body parts from the different dissection tables to be placed or 'thrown' in plain coffins. Hospital instructions prescribed the gathering of all parts of each separate corpse in the corresponding coffin bearing the name of the patient, but members were often missing or fused with other human remains. Because of the destructive nature of succeeding dissections, coffins also contained indefinable tissue and bodily fluids, in which there remained nothing identifiable of the original pauper corpse. ${ }^{1}$ In Great-Britain, where anatomy riots were common place, critics used such evidence of the disrespectful treatment of the poor to contest the Anatomy Act of 1832. The act authorized institutions such as hospitals and workhouses to allocate the bodies of the deceased to medical faculties. In contrast to the burial clause of this act, which contained the word 'body' to describe what was eventually placed in the coffin, public scandals revealed that the end products of dissections were nothing more than waste material without reference to the identity of the deceased (MacDonald, 2011, pp.11-17).

Elizabeth Hurren has recently urged scholars to scrutinize the differences between the 'anatomy burial' and 'pauper funeral'. The frequent use of the overall term of 'pauper burial', has impeded a consideration of the complexity of both practices and the different meanings paupers attached to them (Hurren, 2012, pp. 41-73). In the Brussels hospitals, families could only prevent an anatomy burial by meeting the funeral expenses of the 
coffin and hearse. My research of the hospital archives, however, has revealed that letters written both by the nineteenth-century poor and hospital administrators mainly mention 'pauper burials', which often refers to the burial of dissected remains, but can also point to simple funerals financed by burial societies or poor families who had been able to pay for the burial. Families were frequently creative in searching for financial resources or ways to ensure a more decent burial. Even if relatives could not claim the corpse because of a shortage of money to pay for both the coffin and the hearse, they sometimes came to deliver a self-selected coffin. ${ }^{2}$ Anatomy burials, on the other hand, were known in the popular imagination as 'dog burials'. What was left of the body after the autopsy and dissection, was brought as soon as possible to the cemetery by means of a collective transport service. Families especially rejected the plain flat coffins without covering or ornamentation that were used for the burials of unpaying hospital patients. Although hospital administrators were aware of the poor's sensibilities, they did not think it worthwhile to introduce more expensive pentagonal coffins similar to the ones delivered to the relatives of paying patients. ${ }^{3}$

Scholars have mostly connected such funerary expenditure and the material aspects of burials to the social status of the deceased and their relatives. They explained the antipathy of the poor toward anonymous burials in terms of disgrace, pointing at the social exclusion from the local community if paupers failed to take care of a 'respectable' funeral. (Laqueur, 1983; Richardson, 1987, pp. 266-267; Sappol, 2004, pp. 34-39). Such an approach, however, disregards the emotional and cultural significance of the corpse in the eyes of survivors. In recent decades the experiences of the poor have received more attention. Julie Marie Strange has, for instance, stressed the importance of interpersonal dynamics of working-class responses to death. As she has shown, paupers invested meaning in mourning customs and material symbols of loss as a way of expressing their grief. The poor's abhorrence of anonymous burials stems from their lack of power to claim ownership over the bodies of their loved ones (Hurren \& King, 2005; Strange, 2003, 2005).

Relatives were often shocked by the indifferent attitude of hospitals regarding the dead bodies of paupers, visible in the deplorable settings where the deceased were presented to the public. The small mortuary where different bodies were simultaneously stored was the only place where relatives could see the corpse a last time. According to one relative, nothing in this room indicated the human respect towards the dead. In the hospital of Saint-Jean, for instance, relatives were confronted with uncovered corpses, the eyes unclosed. ${ }^{4}$ Families sometimes attempted to improve the material conditions of the pauper burial by providing hospital staff with screws to close the coffin. Throughout the nineteenth century, however, hospital administrators were reluctant to change the usual and violent nailing of the coffin, which made a strong impression on the poor. According to one complaining family member, whose floral wreath had been put on the wrong grave, funerals for the poor lacked decency:

It would be good, gentlemen and members of the central administration of hospitals and workhouses, if you could occasionally and unexpectedly attend the burials of paupers so that you can see what happens there! As I recently stated in the newspaper, you would understand that the pauper who distrusts the hospital, maybe has a little to complain about. $^{5}$ 
Rumours circulating in the popular quarters of Brussels about the treatment of pauper copses were reinforced by obscure communications with relatives of the dead. Most of the complaints preserved addressed to public hospitals dealt with the neglect of hospital servants to inform relatives about the death of family members. If uninformed relatives showed up 24 hours after the declaration of death, the body had already been transported to the dissection room. In such cases of anatomy burials, hospital staff was required to state that the burial had already taken place. ${ }^{6}$ The overall aura of secrecy shrouding both anatomy burials and pauper funerals was also apparent in attempts to prevent families from coming near the body. According to instructions issued by the central administration of hospitals and workhouses, all family members were allowed to see the corpse. However, managers of hospitals believed it important to discourage relatives from coming face to face with the 'sad spectacle' of death because of the powerful impression it might possibly make. If the public insisted, hospitals could grant permission to see the body before the post-mortem examination or exceptionally afterwards, on the condition that the clothes disguised autopsy incisions on the body. ${ }^{7}$

During the nineteenth century, hospitals were urged to introduce some improvements to the material surroundings of the anatomy burial out of public health concerns. Coffins, for instance, often contained splits through which blood and unpleasant smells escaped. Complaints about faulty material and vapours leaking out of the hearse on public roads pushed physicians and public health experts to take action. According to physicians, a mere glimpse of the hospital hearse had such a profound impact on people that they could even imagine the smell of its content. ${ }^{8}$ Especially from the 1870 s onwards, hospitals introduced measures to improve both the reputation and sanitary conditions of burials. It was decided to stuff the jointures of all coffins with pitch and to soak anatomized corpses with chemical substances. Those material circumstances that were important to relatives, however, such as the setting in which the dead were viewed and the style of the coffin in which they were placed, remained unchanged.

\section{Ideological struggle over the corpse}

In the second half of the nineteenth century, the conditions of the pauper funeral were increasingly contested as a result of ideological tensions in Belgium. This period witnessed a political conflict - in international literature studied under the name of the 'culture war' - between Catholics and the increasingly anticlerical Liberals (Clark \& Kaiser, 2006). The origins of these ideological tensions trace back to the liberal constitution of Belgium (1831), which had allowed the Catholic Church to manifest itself in all areas of society through institutions and associations. In this way, clergymen were able to administer official cemeteries, burial transports and rituals. Around 1850, however, the Catholic burial became a central issue of concern for freethinkers. According to Catholic principles, only Catholics could be interred in consecrated ground, as a result of which freethinkers ended up with suicide victims and criminals in a remote corner of the cemetery, known as the 'dog's hole'. Civil burials were a response to these practices. Following the first Belgian civil burial in Ghent in 1858, such burials gained support in large Belgian cities, where they were organised as collective, public events and political manifestations, strengthening a shared anti-Catholic identity. The burials and funeral marches often provoked the violent protest of clergymen. Equally, the construction of the first civil cemeteries in Brussels, Ghent, Liège and Antwerp, where 
Catholics were interred beside non-Catholics and the unbaptised, resulted in local political struggles and incidents. During the ideological conflict between Liberals and Catholics, Belgian local authorities gradually gained control of the organisation of burials and cemeteries (De Spiegeleer, 2015; Lamberts, 1986; Witte, 2006).

In this context, the deplorable conditions of pauper burials were brought to public attention from the end of the 1860s onwards. The first anticlerical mutualist burial societies were founded in Brussels, aimed at civil burials without the interference of priests. Similar societies were also created in France in the 1860s (Kselman, 1993, p. 106; Lalouette, 1997, p. 32). Uniting liberals and the growing socialist movement, the societies recruited their members from the working and middle classes. By paying an annual or monthly fee, people could apply for membership of an association such as L'Affranchisement (1854), Les Solidaires (1857) and La Libre Pensée (1863), the last of which became the most influential anticlerical organisation. Funded by members' subscriptions and donations, the societies provided for decent funerals in the presence of fellow members, on the condition that members had died according to the 'rules', that is without permitting a priest at their deathbed (La libre pensée, 1867, Les solidaires, 1863). The dissemination of these societies made Catholics realize that the Catholic pauper burials in Brussels left much to be desired. Paupers who rejected the usual plain coffins and collective body transports delivered to indigents on the parish, it was argued, easily fell victim to anticlerical societies (Assemblée générale des catholiques en Belgique: Première session à Malines, 18-22 août 1863, 1864, pp. 9-10).

In 1863, 1864 and 1867 this matter was raised several times during three Catholic congresses that were organised in Mechelen, the seat of the Belgian Episcopate. Uniting the Belgian episcopate and international clerical leaders, the congresses stimulated the foundation of Catholic newspapers, local organizations and societies, thereby disseminating Catholicism in all social and political domains of society. In response to the success of anticlerical burial societies, the members attending the conference proposed founding similar associations in Brussels for the organization of decent religious funerals. According to the president of the General Assembly of Catholics in Belgium, 'it is certain that nothing has such a profound impact on paupers, and nothing predisposes someone more in favour of religion, than the care devoted to them and the respect surrounding their mortal remains' (Assemblée générale des catholiques en Belgique: Troisième session à Malines, 2-7 septembre 1867, 1868, p.12). In Brussels, the Friendly Society of Sainte-Barbe, which was founded in 1864, took care of the transportation of the dead, a celebration of a Mass with the corpse present, and guaranteed that relatives would be informed about the time of the funeral.

In the public hospitals of Brussels, the society was well-known because of its persistent attempts to provide for every Catholic deceased a Catholic mass in the hospital chapel, the only funeral room present. Until the end of the 1880's, Catholic masses were the only institutionalized burial customs in place. Civil, protestant and Jewish rituals mostly had to take place ad hoc in the caves of the hospital of Saint-Pierre or in the corridor in front of the mortuary in the hospital of Saint-Jean. The hospitals hosted and employed a priest who took care of the Catholic funerals in the chapel. However, the priest only organized paid masses for relatives who had claimed a corpse. By its own account, the Society of Sainte-Barbe experienced many difficulties in organizing religious ceremonies for the poor because of the strict hospital regulations. Nonetheless, they took care of a high number of hospital funerals, reaching up to 1279 masses in 1866 
because of an epidemic (Assemblée générale des catholiques en Belgique: Troisième session à Malines, 2-7 septembre 1867, 1868, pp. 373-375, 'Association de Sainte-Barbe, à Bruxelles, pour l'enterrement des Catholiques indigents: Statuts', 1865, pp. 598-602).

An argument common to much Anglo-Saxon scholarship stipulates that the poor fearfully subscribed to mutual burial societies to avoid anatomization. According to Ruth Richardson, the rise of such associations is tied up with the introduction of the British Anatomy Act (Hurren, 2007, pp. 195, 203; Richardson, 1987, pp. 270-281, 1989, pp. 116-117; Sappol, 2004, p. 135). Indeed, in Belgium and Germany associations limited the number of bodies delivered to the autopsy service and medical faculty by making claims on them. In Vienna, on the other hand, they arranged for the burial of dissected human remains (Buklijas, 2008, p. 582-583; Piechocki, 1965, p.76). The increasing number of interventions of burial societies was regarded as highly problematic by hospital administrations in Brussels at the end of the nineteenth century. Contrary to other cities such as Louvain and Ghent, where hospitals were not alarmed by the intervention of burial societies, the high numbers of claims in Brussels strengthened the existing problem of a body shortage for medical and anatomical research (Claes \& Huistra, 2016, p.26-53). ${ }^{9}$ There is no evidence, however, to support the contention that the Belgian associations were primarily concerned with the prevention of dissections. Instead, hospital records suggest that they saw it as their task to provide a decent burial, including a solid coffin and a ceremony according to their respective ideological principles. While civil funerals required hospitals to clear funeral rooms of church related symbolism, Catholic ceremonies were held in presence of meaningful objects such as holy-water fonts. To meet the demands of both groups, hospitals bought black palls with removable Catholic crosses. ${ }^{10}$

The political tensions in the second half of the nineteenth century marked the end of the privileged position of the Catholic Church within public hospitals. Whereas, in the first half of the nineteenth century, the priest attached to a given hospital was allowed to offer his services to dying patients professing a religious affiliation other than Catholic, the regulations of 1859 only stipulated the availability of services of all church representatives. ${ }^{11}$ The dominance of Catholic funeral rites equally decreased with the introduction and increasing regularity of civil burials in the hospitals of Brussels. On the eve of the First World War they were organized on an almost daily basis. In this context, the liberal city council of Brussels, whose policy shows the influence of anticlerical voices, pushed through the introduction of a separate funeral room beside the existing Catholic chapel, where non-Catholic burial services could take place.

The fact that the chapel was the only equipped space where relatives could pay their last respects to the bodies of the dead was first brought to the fore by relatives and Belgian journalists: 'The Catholic church still comes off best despite the constitution which states that all religions are equal before the law.' ${ }^{12}$ According to a lawyer who denounced a civil ceremony in the hospital Saint-Jean, it was obvious to those attending that the hospital administrators were indifferent to civil ceremonies. The funeral was organized outside in the courtyard in rainy weather. To everyone's astonishment, the body of the deceased was placed next to a urinal, the face uncovered. The lawyer added, caustically, that in case of future funerals, he would recommend an umbrella to protect the corpse. ${ }^{13}$ Following this and other complaints, the liberal city council of Brussels responsible for the management of the public hospitals, condemned the poor sanitary conditions in the existing mortuaries, as well as the lack of decency and respect in the 
case of funerals of freethinkers and families of religions other than Catholicism. On repeated request of the council, funeral rooms were constructed in both hospitals, in which families and friends of the deceased could gather before and during the funeral service. At the end of the nineteenth century, the ideological tensions in Brussels resulted in the provision of differentiated burials for each ideological group.

\section{Softening the impression of the pauper burial}

The changing nature of correspondence between hospital administrators, the central commission of hospitals and workhouses, and the Mayor and Aldermen regarding funeral rooms also testifies to a re-evaluation of the pauper burials of claimed bodies. Whereas ideological concerns incited the debate, letters from 1885 until 1887 show an increasing sensitivity towards the sentiments of relatives of the deceased poor. In 1887 it was decided to offer the funeral rooms to anyone who had claimed a corpse, regardless of their religion or financial situation. ${ }^{14}$ Charles Buls, mayor of Brussels from 1881 until 1899, was the main moving force behind changes to the disposal of pauper corpses. On several occasions he took the complaints of relatives of dead patients to heart, and persuaded hospital administrators that pauper burials should be carried out with the same respect as the burials of wealthy hospital patients. ${ }^{15}$ After all, the bad reputation of public hospitals did not accord with the enlightened view of progress shared by liberals such as Buls, who stressed the importance of a well-organized society through modern institutions. In his personal writings, Buls asserted that 'magnificent' hospitals, anatomical schools and amphitheatres are proof of the scientific organization of knowledge in 'the modern age' (Buls \& Bots, 1987, pp. 103-104; Bützler-Vanneste, Bots, Peeters, \& Rigaux, 1987; Peeters, 1982).

From 1881 onwards, the city administration of Brussels took over the monopoly of the church had held in transporting the dead to cemeteries, including the free transport of pauper corpses. In accordance with this new responsibility, respect for the poor assumed greater importance on the municipality's agenda. In a meeting with the hospital administrators, the mayor urged them to pay more attention to the material conditions of pauper funerals, in the same way as the Catholic Church cared for the deceased. ${ }^{16}$ More significant, however, was the pressure of Socialism from the 1880s onwards. Brussels became one of the main centres of strikes and violent demonstrations. In their combat against class inequality and in favour of universal suffrage, socialists emphasized the inferior treatment of the poor in hospitals. The Socialist press portrayed hospitals as 'temples of suffering' from which sick paupers could not escape (Claes \& Huistra, 2016, p. 32). In the newspaper Le Peuple, which appeared in Brussels from 1885 onwards, incidents were reported about pauper funerals and dissections, stimulating existing rumours about the public hospitals. Afraid of socialist intruders and manifestations, hospitals even adopted a regulation to prevent the use of flags or symbols by attendants of the hospital funerals in $1898 .{ }^{17}$

Because of their emotional and social commitment to the body, families actively strived for a proper treatment of the deceased. They nearly always demanded to see the corpse, to assure themselves of the identity of the body and the presence of recognisable clothes in the coffin. According to the hospital administrators, it was impossible to comply with sanitary regulations specifying the closure of coffins one hour before the funeral, as family members and friends often presented themselves late in the mortuary 
to see the dead. Their demands to be present during the laying of the dead in the coffin were based on deep grounded suspicions that coffins did not always contain the right corpse or that the hair of female patients was frequently cut and sold. The social pressure of relatives left hospital staff no option but to yield to the demands of families who insisted on their rights to pay their last respects to the deceased. Conflicts in the past had shown that relatives could disturb the peace in the hospital by protesting violently or by threatening to unearth the corpse. ${ }^{18}$

To meet the concerns of the poor, hospitals gradually improved the material conditions surrounding the corpse. Many measures were taken to soften the impression of the pauper burial. Instead of nailing the coffin in presence of the relatives, hospitals started to use screws to close the coffin less violently from 1905 onwards. Simple flat coffins were replaced by pentagonal coffins, stuffed with red ochre. To keep people from confronting death on the corridors of the hospital, black cloth was bought to ensure a decent transport from the mortuary to the funeral room. In 1910, there was even a discussion as to whether hospitals should place small pillows under the heads of corpses. At the demand of families, the administrator of hospital Saint Jean defended the added element of pillows, yet the introduction of this custom was judged too expensive in the end. The turn of the century brought with it a new respect for the human remains of the poor and the sentiments of relatives in hospitals. The abolition of collective body transports in favour of individual transports, so as to make the trip to the cemetery less painful for family members and friends accompanying the deceased, attests to this new sensitivity ('Service des inhumations', 1904). ${ }^{19}$

\section{The individual pauper corpse}

Historians have argued that a cult of death arose in the nineteenth century, transforming the relationships between survivors and the dead. The rise of ostentatious funerals among middle classes and embalming practices for funerary purposes, which produced aestheticized, lifelike corpses, are clear indications of an increasingly sentimental mourning culture (Buklijas, 2008, pp. 580-581; Carol, 2011, 2015; Deblon \& Wils, 2017; Tarlow, 2002). In this respect, the increasing attention paid to the outward appearance of the corpse and its burial have often been referred to in relation to the individualization of death (Ariès, 1977). The changing burial standards in the Belgian hospitals reflect this broader trend. Complaints about the outward appearance of corpses at the end of the nineteenth century show that new ideas about the look and care of each individual corpse started to circulate within the hospitals. Significantly, this period witnessed the arrival of higher numbers of paying patients as hospitals transformed from utilitarian institutions into renowned medical centres (Havelange, 1987, pp. 83-94). Middle class families of dead patients had higher expectations, and made more demands, in terms of the appearance of the dead, as they were used to well-cared-for funerals. In 1886, for instance, the son of a dead patient who had paid in advance for his hospital treatment complained about the absence of decent 'funerary toilettes'. He offered the remainder of the prepayment of his father's stay in the hospital to the municipality 'for the paupers of Brussels'.20

The new sensitivity towards the individual pauper corpse implied an increasing recognition of the desires of the deceased themselves. At the turn of the century societies, families and hospitals increasingly pointed to the dying wish of patients. In 1902, for 
example, a staff member of the hospital was punished after neglecting a patient's dying wish to see his wife and son one last time. ${ }^{21}$ In freethinking circles in particular, liberals and socialists stressed the individual rights of the deceased, in this way preventing the organization of a Catholic burial against the will of the dead (Kselman, 1988, p. 327). To this end, anticlerical burial societies reminded hospital administrators of the wishes that dead hospital patients had expressed concerning their burial in wills. Often, civil burials caused traumatic conflicts within ideologically divided families. Catholic survivors regularly disregarded the dying wish of the deceased and instead attempted to organize a Catholic burial (Witte, 2006, p. 118). In 1911, the widow of a freethinker lied to the hospital administrator of Saint-Pierre about her husband's last wishes concerning a civil burial, which he had put down in his will. She stated that the whole of her family adhered to the Catholic religion and took care of the funeral arrangements. During the funeral, members of the anticlerical society Libre Pensée complained about the presence of religious objects such as a holy-water font and palls, after which the objects were immediately removed on their request. In response to the association the hospital administration declared that 'The hospital always recognises the last wishes of the deceased regarding the organisation of the burial. ${ }^{22}$

The introduction of the principle of consent in the hospitals of Brussels equally testifies to an increasing attention to the desires of poor hospital patients. In 1889, the city council changed hospital regulations concerning pauper burials. Following the new rule, close family members could always claim a corpse, regardless of their financial situation. The city council asserted that it was cruel to refuse the right of poor family members to take possession of a corpse in favour of medical education. In such cases, the municipal administration would cover funeral expenses. ${ }^{23}$ Cultural historian Tinne Claes has argued that consent gradually became the foundation for the procurement of corpses by anatomical theatres. From 1900 onwards, individuals increasingly appealed for the right to veto or approve a dissection. In the long term, this development led to the introduction of anatomical gift acts (Claes, 2017). Nineteenth-century hospitals, however, retained their exclusive right to make decisions regarding autopsies on paying and non-paying patients, as long as the return of the body was done 'decently'. To cope with the shortage of corpses for post-mortem examinations, especially after the revised hospital regulations in 1889, Belgian anatomists successfully redefined the autopsy as a respectable operation. According to them, the autopsy, unlike the mutilating dissection, recognized the integrity of the human corpse by leaving important external features of the deceased untouched. After the post-mortem examination, physicians put the organs back into place, stitched up the incisions and clothed the dead patients, in this way hiding the autopsy from relatives who came to see the body (Claes \& Huistra, 2016, pp. 39-45). This pragmatic rule based on tacit consent that allowed hospitals to continue bodily research on claimed bodies, could cause heart breaking scenes in the mortuary. Relatives, convinced of their right to veto a post-mortem examination, responded with agitation if they were confronted with the truth. In 1902, a widow noticed the blood traces on the clothes of her dead husband. Despite strong resistance of the hospital staff, she demanded to see the body, in this way discovering that his corpse had been autopsied. ${ }^{24}$

Significantly, the new hospital regulations only recognized the rights of close family members, including the husbands and wives, and the children and parents of the deceased. Hospital boards were more reluctant to assign other family members and burial societies equal rights to ownership for fear of a drop in the available bodies for post- 
mortem examinations. On several occasions hospitals even tried to deny societies their rights to bury dead patients. Such a regulation, however, proved untenable in practice. The insistence of burial societies on claiming the bodies of poor members was difficult to resist. In most cases, hospitals had to give in to their claims, because societies continued to make complaints or threatened to create a public scandal in order to attain their goal. ${ }^{25}$ Without family or membership of a society, however, poor hospital patients were usually powerless. In 1887, for instance, a priest wrote to the administrator of Saint-Jean about his parishioners, who were tormented by the thought of dying of an illness in a hospital. The Catholic paupers had asked him to take care of their funerals. This was a bridge too far for the hospital administration. If priests and other ministers of religion, as well as friends and acquaintances could claim corpses, too few corpses would remain for dissection. 'Strangers', it was asserted, such as the priest, were not allowed to claim corpses. $^{26}$

\section{Conclusion}

Dissected and buried anonymously, the nineteenth-century pauper corpse powerfully evokes a sense of suffering and social exclusion. Here I challenge this dominant view within scholarship by foregrounding the complex interaction of different political and social actors with an interest in the disposal of the bodies of the poor. I argue that the end of the nineteenth century witnessed a growing focus on the individuality of the pauper corpse. The case of the city of Brussels shows that the increasing sensitivity of hospital administrators towards the material conditions of burials of indigent hospital patients is linked to broader socio-political developments. From the 1860s onwards, Brussels became a site of ideological conflict in which anticlerical liberals, Catholics and socialists tried to assert their influence on society by pushing for the respectful handling of pauper bodies. In this context, mutualist burial societies and the local authorities became the most important proponents, urging hospital administrators to improve the material setting surrounding each individual corpse, including the coffin and symbolic objects. Whereas the beginning of the debate in the 1860s and 1870s was dominated by Catholic and anticlerical concerns regarding religious burials, after 1885 it was increasingly marked by the pressure of socialism.

Parallel to this socio-political debate, hospitals were increasingly confronted with new burial standards and ideas about individual corpses that were common place in nineteenth-century middle class families. These cultural developments and ideological struggles together resulted in a greater emphasis on the individual corpse and the last wishes of patients, whether dead or alive. Following the rise of civil burials within the public hospitals, administrators increasingly had to take account of the burial desires of the dead. Yet, I argue in this article that social relationships marked the boundaries of the individualization shift in the public. Hospital administrators only paid attention to the last wishes and outward appearance of the pauper body if there were close family members or burial societies involved. Poor hospital patients without social relations often ended upon the dissection table and were buried anonymously afterwards. 


\section{References}

Alberti, S. J. M. M. (2011). Morbid curiosities: Medical museums in nineteenth-century Britain. Oxford: Oxford University Press.

Ariès, P. (1977). L'homme devant la mort. Paris: Seuil.

Assemblée générale des catholiques en Belgique: Première session à Malines, 18-22 août 1863. (1864). Brussels: Goemaere.

Assemblée générale des catholiques en Belgique: Troisième session à Malines, 2-7 septembre 1867. (1868). Brussels: Victor Devaux.

Association de Sainte-Barbe, à Bruxelles, pour l'enterrement des Catholiques indigents: Statuts. (1865). In Assemblée générale des catholiques en Belgique: Deuxie session à Malines, 29 août-3 septembre 1864 (pp. 598-602). Brussels: Victor Devaux.

Brouckère, C. de, \& Tielemans, F. (1834). Répertoire de l'administration et du droit administratif de la Belgique. Bruxelles: Weissenbruch.

Brouckère, C. de, \& Tielemans, F. (1838). Répertoire de l'administration et du droit administratif de la Belgique. Bruxelles: Weissenbruch.

Buklijas, T. (2008). Cultures of death and politics of corpse supply: Anatomy in Vienna, 1848-1914. Bulletin of the History of Medicine, 82(3), 570-607.

Buls, C., \& Bots, M. (1987). Het dagboek van C. Buls. Gent: Liberaal Archief.

Bützler-Vanneste, Y., Bots, M., Peeters, Y. J. D., \& Rigaux, H. (1987). Karel Buls, wereldreiziger met een hart voor Brussel (1837-1914). Brussels: Willemsfonds.

Carol, A. (2011). Pudeurs et manipulations médicales du cadavre, (France XIXe siècle). Histoire, médecine et santé, 63-75.

Carol, A. (2015). L'embaumement, une passion romantique, France XIXe siècle. Seyssel: Champ Vallon. 
Claes, T. (2017). 'By what right does the scalpel enter the pauper corpse?': Dissections and consent in late nineteenth-century Belgium. Social History of Medicine (forthcoming).

Claes, T., \& Huistra, P. (2016). 'Il importe d'établir une distinction entre la dissection et l'autopsie': Lijken en medische disciplinevorming in laatnegentiende-eeuws België. BMGN - Low Countries Historical Review, 131(3), 26-53.

Clark, C., \& Kaiser, W. (Eds.). (2006). Culture wars: secular-catholic conflict in nineteenth-century Europe. Cambridge: Cambridge university press,.

De Spiegeleer, C. (2015). Sterven, begraven en herdenken van koninklijke en politieke elites in België, 1830-1940. Een politiek-culturele studie. Vrije Universiteit Brussel.

Deblon, V., \& Wils, K. (2017). Overcoming Death: Conserving the Body in NineteenthCentury Belgium. In S. McCorristine (Ed.), When is Death?: Interdisciplinary Perspectives on Death and its Timings. Basingstoke: Palgrave Macmillan (forthcoming).

Fahlander, F., \& Oestigaard, T. (Eds.). (2008). The materiality of death: Bodies, burials, beliefs. Oxford: Archaeopress.

Hallam, E., \& Hockey, J. (2001). Death, memory and material culture. Oxford: Berg.

Hallam, E., Hockey, J., \& Howarth, G. (1999). Beyond the body: Death and social identity. London: Routledge.

Harper, S. (2010). The social agency of dead bodies. Mortality, 15(4), 308-322.

Havelange, C. (1987). L'hôpital à la croisée des chemins: la question des malades payants. Annales Belges d'Histoire Des Hôpitaux et de La Santé Publique, 25, 83-94.

Houlbrooke, R. A. (Ed.). (1989). Death, ritual and bereavement. London: Routledge. 
Hurren, E., \& King, S. (2005). 'Begging for a burial': Form, function and conflict in nineteenth-century pauper burial. Social History, 30(3), 321-341.

Hurren, E. T. (2007). Protesting about Pauperism: Poverty, Politics and Poor Relief in Late-Victorian England, 1870-1900. Woodbridge: Boydell Press.

Hurren, E. T. (2012). Dying for Victorian medicine: English anatomy and its trade in the dead poor, c. 1834 - 1929. Basingstoke: Palgrave Macmillan.

Jalland, P. (1996). Death in the Victorian family. New York: Oxford University Press.

Kselman, T. (1988). Funeral conflicts in nineteenth-century France. Comparative Studies in Society and History, 30(2), 312-332.

La libre pensée: Association pour l'enterrement civil et pour l'émancipation des consciences par l'instruction: Statuts. (1867). Louvain: Savoné.

Lambert, H., \& McDonald, M. (Eds.). (2013). Social bodies. Oxford: Berghahn Books.

Lamberts, E. (1986). De kerkhovenkwestie. In L'initiative publique des communes en Belgique 1795-1940. Actes du 12e colloque international. Bruxelles: Crédit communal de Belgique.

Laqueur, T. (1983). Bodies, death, and pauper funerals. Representations, (1), 109-131.

Le Breton, D. (1993). La chair à vif: Usages médicaux et mondains du corps humain. Paris: Métailié.

Les solidaires: Association pour l'enterrement civil, caisse d'assurance mutuelle, de secours fraternel, de prévoyance et de propagande. Statuts. (1863). Brussels: Brismée.

MacDonald, H. (2011). A Body buried is a body wasted: The spoils of Human dissection. In D. S. Ferber \& M. S. Wilde (Eds.), The body divided: Human beings and human 'material' in modern medical history (pp. 9-27). Farnham: Ashgate. 
MacDonald, H. P. (2006). Human remains: Dissection and its histories. London: Yale University Press.

Menenteau, S. (2009). Le corps autopsié à l'épreuve au XIXe siècle. In F. Chauvaud (Ed.), Corps saccagés: Une histoire des violences corporelles du siècle des lumières à nos jours (pp. 25-40). Rennes: Presses universitaires de Rennes.

Menenteau, S. (2013). L'autopsie judiciaire: histoire d'une pratique ordinaire au XIXe siècle. Rennes: Presses universitaires de Rennes.

Pearsall, C. D. J. (1999). Burying the Duke: Victorian mourning and the funeral of the Duke of Wellington. Victorian Literature and Culture, 27(2), 365-393.

Peeters, Y. J. D. (1982). Karel Buls (1837-1914), burgemeester op de raaklijn van twee kulturen. Antwerp: De Nederlanden.

Piechocki, W. (1965). Zur Leichenversorgung der halleschen Anatomie im 18. und 19. Jahrhundert. Acta Historica Leopoldina, 2, 67-105.

Richardson, R. (1987). Death, dissection and the destitute. London: Routledge and Kegan Paul.

Richardson, R. (1989). Why was death so big in Victorian Britain? In R. A. Houlbrooke (Ed.), Death, ritual and bereavement (pp. 105-117). London: Routledge.

Sappol, M. (2004). A traffic of dead bodies: Anatomy and embodied social identity in the nineteenth-century America. Princeton: Princeton university press.

Schwartz, M. (2015). Dead matter: The meaning of Iconic corpses. Minnesota: University of Minnesota Press.

Service des inhumations. (1904, June 11), p. 2.

Strange, J.-M. (2003). Only a pauper whom nobody owns: Reassessing the pauper grave c. 1880-1914. Past \& Present, (178), 148-175. 
Strange, J.-M. (2005). Death, grief and poverty in Britain, 1870-1914. Cambridge: Cambridge University Press.

Tarlow, S. (2002). The aesthetic corpse in nineteenth-century Britain. In Y. Hamilakis, M. Pluciennik, \& S. Tarlow (Eds.), Thinking through the body: Archaeologies of corporeality (pp. 85-98). New York: Plenum/Kluwer Academic.

Watson, N., \& Cunningham-Burley, S. (Eds.). (2001). Reframing the body. Basingstoke: Palgrave.

Witte, E. (2006). The battle for monasteries, cemeteries and schools: Belgium. In C. Clark \& W. Kaiser (Eds.), Culture wars: secular-catholic conflict in nineteenth-century Europe (pp. 102-128). Cambridge: Cambridge university press,.

Wolffe, J. (2000). Great deaths: Grieving, religion, and nationhood in Victorian and Edwardian Britain. Oxford: Oxford University Press.

\section{Notes}

\footnotetext{
${ }^{1}$ Archives Social Services of Brussels (ASSB). Affaires Générales, 35. Dossier la remise préalable à l'une des hôpitaux de tout cadavre destiné à l'université, letter director of hospital St Pierre to the central commission of social services, 4 December 1886. Brussels; Archives Social Services of Brussels (ASSB). Affaires Générales, 38. Letter director hospital St Pierre to the central commission of social services, 17 June 1864. Brussels.

${ }^{2}$ Archives Social Services of Brussels (ASSB). Affaires Générales, 130. Dossier l'article paru dans le journal Le Peuple au sujet de l'inhumation de l'enfant Jean Mattau, letter director Hospital St Pierre to Mr. Vanderton, 20 December 1886. Brussels.

${ }^{3}$ Archives Social Services of Brussels (ASSB). Affaires Générales, 113. Dossier la plainte de la veuve Pouillon relative à l'enterrement de son mari, letter widow Pouillon to the Mayor and the Board of Aldermen, 4 January 1885. Brussels.

${ }^{4}$ Brussels City Archives (BCA). Bienfaisance, S 107-2. Dossier dépôts mortuaires des hôpitaux, letter Ferdinand Dupont to Mayor Charles Buls, 12 January 1886. Brussels.

${ }^{5}$ Archives Social Services of Brussels (ASSB). Affaires Générales, 114. Dossier la réclamation de M. Delevoy au sujet de la destination donnée à la couronne qu'il avait transmise pour $\mathrm{Mr}$ Duffant, décédée à St Jean, letter M. Delevoy to the central commission of social services, 31 August 1888. Brussels.

${ }^{6}$ Archives Social Services of Brussels (ASSB). Fonds du directeur, 292. Dossier cadavres, décès et inhumation. Brussels.

${ }^{7}$ Archives Social Services of Brussels (ASSB). Fonds du directeur, 292. Dossier cadavres, décès et inhumation, instructions for the hospitals of St Pierre and St Jean, 13 March 1892. Brussels.
} 
${ }^{8}$ Archives Social Services of Brussels (ASSB). Affaires Générales, 76. Dossier les instructions données pour éviter l'odeur répandue par les cadavres des personnes décédées dans les hôpitaux, letter director St Pierre to the central commission of social services, 13 August 1880. Brussels.

${ }^{9}$ Archives Social Services of Brussels (ASSB). Affaires Générales, 107. Analysis of responses to the letter of the central commission of social services of 30 April 1875, 20 May 1875. Brussels.

${ }^{10}$ Archives Social Services of Brussels (ASSB). Affaires Générales, 76. Dossier l'achat d'un drap mortuaire pour recouvrir les cercueils des personnes, venant à décéder dans les hôpitaux en dehors de toute communion religieuse, letter central commission of social services to directors St Pierre and St Jean, 22 February 1876. Brussels.

${ }^{11}$ Brussels City Archives (BCA). Bienfaisance, S 107-2. Hospital regulations, 30 May 1823 and 25 June 1859. Brussels.

${ }^{12}$ Brussels City Archives (BCA). Bienfaisance, S 107-2. Newspaper cutting, [1885]. Brussels.

${ }^{13}$ Archives Social Services of Brussels (ASSB). Affaires Générales, 34. Dossier concernant les dépôts mortuaires à St Jean et à St Pierre, letter Louis Orts to central commission of social services, 23 November 1887. Brussels.

${ }^{14}$ Brussels City Archives (BCA). Bienfaisance, S 107-2. Dossier dépôts mortuaires des hôpitaux, Correspondance 1885-1887. Brussels; Archives Social Services of Brussels (ASSB). Affaires Générales, 34. Dossier concernant les dépôts mortuaires à St Jean et à St Pierre, Correspondance 1885-1887. Brussels.

${ }^{15}$ Archives Social Services of Brussels (ASSB). Affaires Générales, 113. Dossier la plainte de la veuve Pouillon relative à l'enterrement de son mari; Archives Social Services of Brussels (ASSB). Affaires Générales, 130. Dossier les renseignements demandés par le bourgmestre relative à une plainte faite par les parents de la nommée D'Hert Cath. Décédée à l'hôpital St Pierre à la suite d'une affection charbonneuse, letter central commission of social services to director St Pierre, 7 July 1885. Brussels.

${ }^{16}$ Archives Social Services of Brussels (ASSB). Affaires Générales, 38. Meeting report of the central commission of social services, 11 November 1889. Brussels.

${ }^{17}$ Archives Social Services of Brussels (ASSB). Affaires Générales, 64. Dossier demande par le collège de savoir si les musiques accompagnant les convois funèbres venant de l'hôpital St Jean ne doivent pas être interdites 1898-1909. Brussels.

${ }^{18}$ Archives Social Services of Brussels (ASSB). Affaires Générales, 39. Dossier les observations de la ville au sujet de la mise en bière des cadavres et de la fermeture des cercueils dans les hôpitaux. Brussels.

19 Archives Social Services of Brussels (ASSB). Affaires Générales, 39. Dossier concernant l'adjudication des cercueils nécessaires en 1911 et 1912 and Dossier concernant la mise en adjudication et de la fourniture des cercueils nécessaires pendant 5 ans à partir du 1 janvier 1901 . Brussels; Archives Social Services of Brussels (ASSB). Fonds du directeur, 292. Dossier cadavres, décès et inhumation. Brussels.

${ }^{20}$ Brussels City Archives (BCA). Bienfaisance, S 107-2. Dossier dépôts mortuaires des hôpitaux, letter Ferdinand Dupont to Mayor Charles Buls, 12 January 1886. Brussels.

${ }^{21}$ Archives Social Services of Brussels (ASSB). Affaires Générales, 133. Dossier la plainte par le collège au sujet de ce qui s'est passé à l'hôpital St Pierre à la suite du décès de Henri De Ro, meeting report, 30 December 1902. Brussels.

${ }^{22}$ Archives Social Services of Brussels (ASSB). Affaires Générales, 35. Dossier concernant la protestation de la Libre Pensée de St Gilles au sujet des conditions dans lesquelles a lieu à l'hôpital St Pierre l'enterrement de sieur Pardaens. Brussels.

${ }^{23}$ Archives Social Services of Brussels (ASSB). Fonds du directeur, 292. Dossier amphithéâtre autopsies dissections, letter municipal administration to central commission of social services, 19 June 1890. Brussels.

${ }^{24}$ Archives Social Services of Brussels (ASSB). Affaires Générales, 133. Dossier la plainte par le collège au sujet de ce qui s'est passé à l'hôpital St Pierre à la suite du décès de Henri De Ro. Brussels.

${ }^{25}$ Archives Social Services of Brussels (ASSB). Affaires Générales, 66. Dossier les observations faites à l'université relativement à la reprise des cadavres. Brussels. 
${ }^{26}$ Archives Social Services of Brussels (ASSB). Affaires Générales, 113. Dossier la remise des cadavres aux seules personnes de la famille non aux ministres des cultes. Brussels. 